\title{
Pembentukan Karakter Remaja Dalam Gereja dan Pendidikan Masa Modern
}

\author{
DEASTRY FANI RANTESALU \\ Lembaga : IAKN Toraja \\ deastryf@gmail.com
}

\begin{abstract}
Abstrak: Pengembangan karaktek remaja yang dilakukan pada masa era modern merupakan suatu tindakan gereja dalam menghadapi pendidikan masa modern ini. Pendidikan yang dilakukan gereja dan dunia belajar sangat bergantung pada setiap karakter yang dimiliki oleh setiap pribadi remaja. Oleh karena itu, gereja yang memiliki peran penting bagi remaja, harus benar-benar membina remaja dengan bijaksana, sama halnya dengan orang tua yang membimbing anaknya menjadi tumbuh dewasa untuk mencapai cita-cita yang diinginkan anak tersebut, artinya bahwa orang tua mensuport anak untuk mempasilitasi anaknya mencapai tujuan yang diinginkan. Maka dari itu, gereja juga harus mempasilitasi remaja dalam pendidikan mereka agar generasi-generasi gereja memiliki generasi milineal yang baik di era modern.
\end{abstract}

Kata kunci : Karakter, Remaja, Gereja,

\section{Pendahuluan}

Dalam suatu pendidikan yang dimiliki oleh anak sebaiknya, terlebih dulu di berikan arah pada masa-masa sekarang dalam masa remaja dan dalam masa modern. Pada dasarnya anak membutukan pembentukan karakter yang dimiliki, setiap anak-anak pasti mempunyai karakter yang berbeda-beda. Untuk itu bagaimana cara orang tua, gereja dalam mendidik anak pada masa modern ini. Dengan cara orang tua dapat berpartisipasi dengan anak melalui hal-hal kecil, yang dapat membuat anak merasa nyaman bersama keluarga dan lingkungan sekitar. Peran gereja juga sanggatlah penting dalam mendidik anak remaja, dengan mempercayakan atau melalukan suatu aktifitas yang ada pada gereja. 
Dengan cara membentuk karakter yang berpotensi dalam gereja, misalnya mengembangkan suatu hobi atau minat bakat dalam melakukan suatu yang ada pada dirinya. Contohnya dalam memainkan alat music seperti, "Piano, Gitar, Keyboard, Kajon" dimainkan pada saat ibadah dalam gereja. Ataupun dalam mengambil bagian pada saat ibadah mari minggu seperti, menjadi Singers, ataupun menjadi Liturgis. Untuk mengembangkan karakter pada anak remaja, dengan cara mempercai suatu kemampuan yang dimiliki sangatlah bagus. Peranan warga gereja juga sangatlah penting untuk mendukung setiap potensi yang dimiliki oleh anak. Dan mempercayai anak dalam melakukan tugas dan tanggung jawab yang ia miliki, dan anak dapat belajar lebih giat.

\section{Tujuan}

1. Mengetahui karakter remaja dalam gereja dan kepribadian remaja.

2. Mengetahui karakter remaja dalam pendidikan masa modern.

3. Dan mengetahui perkembangan psikolok anak remaja

\section{Manfaat}

Mengetahui potensi yang dimiliki anak dalam mengembang suatu karakter yang dimiliki suatu kepribadian remaja. Melalui pengajaran dan pengalaman langsung atau tidak langsung atas manfaat ilmu pengetahuan merupakan sebuah sistem pengetahuan yang pasti dan tidak dapat diragukan. Pada dasarnya ilmu pengetahuan memiliki pendidikan yang sangatlah maju dierah zaman ini, begitu pentingnya pendidikan bagi anak-anak remaja dikalangan ini. Untuk mengetahui apa-apa saja yang telah berkembang di berbagai manca Negara, yang begitu cepat. Karena pendidikan atau ilmu pengetahuan merupakan kodrat yang dimiliki setiap manusia untuk dikembangkan.

\section{Pembahasan}

Pendidikan sebagai sebuah proses, pada masa sekarang, pendidikan sudah harus merujuk kepada adanya suatu konsekwensi logis dan berbagai perubahan perilaku, sikap, dan tata budaya. Maka dari itu pada anak remaja harus ditekankan bahwa suatu perilaku itu sangatlah berpengaruh dalam setiap langkah dan kehidupan kita pada masa ini. Untuk itu pentingnya pendidikan di ajarkan pada anak remaja dapat, membangun relasi yang baik pada setiap orang 
agar dampat membentuk suatu karakter yang lebih baik lagi dari sebelumnya. Dan belajar dari kesalahan yang di lakukan pada saat itu. ${ }^{1}$

Pada dasarnya dalam mendidik anak yang dapat berkarakter yang baik harus terlebih dahulu di jelaskan dengan baik, baik secara materi ataupun melakukan praktek. Untuk mengenalkan anak yang baik dalam berpendidikan yang jauh dari itu. Orang tua juga merupakan peranan yang sangat penting dalam mendidik anak-anaknya. Tak lepas dari itu kebiasaan anak yang berkarakter itu pasti memiliki norma-norma yang di terapkan dalam lingkungan keluarga maupun lingkungan bermasyarakat.

\section{Psikolok anak remaja}

Pada masa remaja merupakan masa dimana individu mengalami berbagai cara serta mencoba peran-peran atau keyakinan baru sambil mencari-cari untuk mencapai identitas ego (berusaha menyakinkan bahwa cara pandang dirinya memiliki kesinambungan dengan masa lalu dan sesuai dengan persepsi orang lain. Maksudnya ialah masa remaja merupakan masa yang memiliki rasa ingin mencari keberadaan lingkungannya sendiri. Selama masa ini, masyarakat secara relative membiarkan remaja bebas dari tanggung jawab dan bebas mencoba berbagai identitas. Pada dasarnya remaja bereksperimen dengan berbagai peran dan kepribadian untuk menemukan identitas seksual, pekerjaan, prestasi atau intelektual, minat, kepribadian, budaya, fisik. Eksperimen ini merupakan usaha yang dilakukan dengan di segaja oleh remaja agar dapat menentukan kesesuaian mereka di dalam dunia.

\section{Pendidikan karakter remaja}

Pendidikan iman sejatinya bukan satu-satunya diperoleh dari pendekatan sekolah formal. Faktanya pada dasarnya iman sangatlah di pengaruhi dengan adanya melalui suatu budaya yang dimiliki sejak lama dan berkembang dengan sangat cepat mempengaruhi keteladanan dan intelerasi individual. Dengan kata lain, kepercayaan yang kita punya bahkan iman yang kita pengang sejak dahulu merupakan sebuah tradisi ataupun kultur dengan cara turun temurun. Tetapi pendidikan yang kita jalani saat ini bukanlah pendidikan iman melainkan pendidikan

\footnotetext{
${ }^{1}$ Rannu Sanderan, "Disiplin Asketisme dan Harmoni Kontribusi Displin Diri bagi Pengembangan Pendidikan Kristen”, Lingua: Jurnal Pascasarjana PAK (29 November 2021)
} 
sekolah dengan cara formal. ${ }^{2}$ Perilaku manusia lebih dominan karena adanya suatu pengamatan yang dipengaruhi oleh suatu proses ikut-mengikut perilaku yang di lakukan orang lain, bahka cara berpakaian orang yang berada diluar sana menjadi tranding satu persatu mulai mengikuti cara berpakaian makar dari itu disebut sebagai meniru gaya ataupun perilaku yang dimiliki orang. 3

Karakter dan kepribadian yang di bentuk melalui proses berubahan minat dan antusiasme merupakan minat yang digemari, dengan sesuatu kegairahan, ataupun gelora semangat yang dilakukan anak dalam mencapai suatu tujuan, mamungkinkan anak mampu meluangkan Kreatifitas dan sanggup menaikkan potensi yang ada pada dirinya. Pada anak membutukan dukungan dari orang tua untuk membangun nilai-nilai yang baik, dalam lingkungan keluarga dan lingkungan bermasyarakat. Seorang anak yang berkatakter pasti mempunyai pendidikan yang baik, yang dapat menerima kritik dari guru-guru dalam proses belajar. Kepribadian seorang anak akan muncul dan makin tumbuh berkat adanya minat yang memicu oleh peneladanan diri yang ditunjukkan antusiasme. ${ }^{4}$

Dalam pembentukan karakter pada anak juga dapat dipengaruhi oleh adanya suatu budaya, yang sering kali diterapkan dalam kehidupan bermasyarakat dan lingkungan sekitar. Dalam jurnal, Rannu Sanderan menjelaskan bahwa merujuk pada praktik pendidikan yang terjadi dalam masyarakat Israel Kuno, dapat dikatakan bahwa tugas ini dipercayakan pada orangtua dan komunitas.para ahli tidak dapat dibuktikan adanya pola pendidikan seperti institusi sekolah modern sekarang ini, namun budaya memberi pendidikan wajib dilakukan oleh orang tua. ${ }^{5}$

\section{Peran gereja pada anak remaja}

Sangat penting untuk melakukan pembinaan pada anak remaja agar, anak remaja dapat bertumbuh semakin kuat dalam pencapaian kedewasaan iman tidak dapat dipungkiri bahwa ada

\footnotetext{
${ }^{2}$ Rannu Sanderan. "Statifikasi Sosial kepemimpinan Tradisional Toraja dalam dinamika demokrasi modern”, jurnal lembaga (2015-2015)

${ }^{3}$ Rannu Sanderan. "Exemplary, Menemukenali Kunci Pendidikan Iman Bagi Anak Dalam Keluarga Dan Pembelajaran Agama Di Sekolah", Lingua: Jurnal PAK (19 November 2021)

${ }^{4}$ Rannu Sanderan. "Exemplary, Menemukenali Kunci Pendidikan Iman Bagi Anak Dalam Keluarga Dan

Pembelajaran Agama Di Sekolah”, Lingua: Jurnal PAK (19 November 2021)

${ }^{5}$ Rannu Sanderan, "Heuristika dalam pendidikan Karakter Manusia Toraja Tradisional”, Lingua: Jurnal Teologi dan Pendidikan Kristen Kontekstual 3, no.2. (Desember 2020)
} 
banyak gereja yang hanya menfokuskan dalam pembanguanan visi gereja tetapi mengabaikan pembinaan gereja yang sesunggunya pada anak. Pembinaan anak remaja, dapat dilibatkan dengan mengambil sebuah pelayanan dalam gereja. Anak juga dapat mengembangkan bakat yang dimiliki pada, alat musik yang di gemarinya ataupun dalam hal lainnya, seperti menari, menyanyi atau mengambil bagian dalam drama anak. ${ }^{6}$

\section{Kesimpulan}

Dalam membangun karakter pada anak terlebih dahulu membangun spiritual remaja yang baik, dengan menjaga hidup dan mengambil sebuah keputusan yang dalam menjalani pengembangan karakter setiap anak. Pada dasarnya anak harus tatap diberikan perhatian yang lebih dengan sebaik mungkin sehingga dalam dunia anak, anak dapat membangun spiritualitas remaja diperlukan dalam menghadapi lingkungan keluarga bahkan lingkungan bermasyarakat. Serta orangtua dan gereja sangat penting.

\section{Saran}

Melalui penulisan ini dapat memberikan pemahaman tentang pembentukkan karakter setiap anak remaja, bagaimana cara mendidik remaja masa kini, sesuai dengan kemampuan yang dimiliki oleh setiap anak dengan cara meningkatkan kemampuan anak yang digemari. Dan perlunya dukungan dari orang tua untuk membatu anak dan mendidik anak kejalan yang benar. Sehingga anak dapat berkarakter dan tidak dapat menyimpang kelak nanti dimasa-masa yang akan datang

\footnotetext{
${ }^{6}$ Rannu Sanderan. "Jabatan Gerejawi dan Peran Perempuan dalam Pelayanan Gereja”, Jurnal S2_Rannu B 5ok
} 


\section{Referensi}

Sanderan, Rannu "Heuristika dalam pendidikan Karakter Manusia Toraja Tradisional",Lingua: Jurnal Teologi dan Pendidikan Kristen Kontekstual 3, no.2. (Desember 2020)

Sanderan, Rannu "Disiplin Asketisme dan Harmoni Kontribusi Displin Diri bagi Pengembangan Pendidikan Kristen", Lingua: Jurnal Pascasarjana PAK (29 November 2021)

Sanderan, Rannu "Exemplary, Menemukenali Kunci Pendidikan Iman Bagi Anak Dalam Keluarga Dan Pembelajaran Agama Di Sekolah”, Lingua: Jurnal PAK (19 November 2021)

Sanderan, Rannu "Statifikasi Sosial kepemimpinan Tradisional Toraja dalam dinamika demokrasi modern", Jurnal lembaga (2015-2015)

Sanderan, Rannu "Jabatan Gerejawi dan Peran Perempuan dalam Pelayanan Gereja", Jurnal S2 _Rannu B 5ok 